\title{
Case Study of Bovine Papilloma Virus in Aceh Cattle in Lhoknga Aceh Besar
}

\author{
Budianto Panjaitan ${ }^{1}$, Syafruddin ${ }^{1}$, Roslizawaty ${ }^{1}$, Muhammad Hasan ${ }^{1}$, Herrialfian \\ Herrialfian $^{2}$, Dwinna Aliza ${ }^{3}$, Hafizuddin ${ }^{4}$, Rahman Alfarisyi ${ }^{5}$ \\ ${ }^{1}$ Clinic Laboratory, Faculty of Veterinary Medicine, Universitas Syiah Kuala, Banda Aceh, Indonesia \\ ${ }^{2}$ Biochemistry Laboratory, Faculty of Veterinary Medicine, Universitas Syiah Kuala, Banda Aceh, Indonesia \\ ${ }^{3}$ Pathology Laboratory, Faculty of Veterinary Medicine, Universitas Syiah Kuala, Banda Aceh, Indonesia \\ ${ }^{4}$ Reproduction Laboratory, Faculty of Veterinary Medicine, Universitas Syiah Kuala, Banda Aceh, Indonesia \\ ${ }^{5}$ Study Program of Veterinary Medicine, Faculty of Veterinary Medicine, Universitas Syiah Kuala, Banda Aceh, \\ Indonesia \\ *Corresponding author. Email: dwinna.aliza@unsyiah.ac.id
}

\begin{abstract}
Bovine papillomavirus (BPV) induces benign tumours of cutaneous or mucosal epithelial in cattle and generally does not cause serious clinical problems in the host. A case of BPV reported in 2-year-old female Aceh cattle in Lhoknga, Aceh Besar. The clinical examination found various sizes of lumps on the head area, facial area (diameter of 1-2 cm), orbital area $( \pm 3 \mathrm{~cm})$, and on the area behind the ear $(5 \mathrm{~cm})$. There was also a wound on the surface of the lumps. Blood of the cattle then collected for haematology examination. The results showed an increase in the number of White Blood Cell (WBC), mean corpuscular haemoglobin concentration (MCHC), platelet (PLT), lymphocytes and monocytes, however a decrease in the number of haematocrit (HCT). Tissue biopsy of the lumps carried out for histopathological examination using Haematoxylin-Eosin (HE) and Masson Trichrome's staining method. Microscopic examination demonstrated hyperkeratosis, acanthosis, and proliferation of epithelial cells to form papilla and colloid, as well as lymphocyte and monocyte infiltration.
\end{abstract}

Keywords: Aceh cattle, bovine papillomavirus, lumps, hyperkeratosis, acanthosis

\section{INTRODUCTION}

Aceh cattle is one of the four Indonesian local cow breeds together with Pesisir, Madura, and Bali cows. This cow is a crossbreed between local cow (Bos sondaicus) and derivative zebu cow from India (Bos indicus) [1]. Aceh cattle have the characteristics as beef cattle with relatively small body performance, firm, and compact with the hump on the back in male, and function mostly to help human daily work $[1,2]$. Aceh cattle have advantages compared to other types of beef cattle, such as able to adapt to tropical environments, good capability against low quality feed, less fat accumulation in meat, relatively resistant to internal and external parasites, good productivity, carcass content of $49 \%$ and meat structure has a finer, denser and better tissue than Brahman and Ongol breed beef [3].

The beef cattle in Aceh Province are mostly raised extensively (traditionally) by grazing them on empty land, moor or pasture, and breeding is done naturally [4]. Therefore, several infectious diseases often infect beef cattle including Brucella, Anthrax, Mastitis, Helminthiasis, Pink Eye, and Septicemia Epizootica (SE), which cause death of the cattle [1]. Furthermore, Aceh cattle was also frequently infected by papillomatosis, which results in decreased production and lead to livestock farmers concerns.

Bovine papillomatosis is a viral disease of cattle characterized clinically by development of multiple shape and size benign tumors termed warts. Several studies reported that the morphology of the warts is cauliflower like, black to greyish in colour, and keratinized [5]. Furthermore, Ugochukwu et al [6] added that the surface of Papilloma warts are rough, irregular, and sessile, with hyperkeratosis and not pain.

Bovine papillomatosis caused by host, site and lesion specific papillomaviruses from Family Papovaviridae namely bovine papilomavirus type-1(BPV-1), BPV-2, 
and BPV-5. Based on virus protein structure, there are six types of bovine papillomavirus. (BPV) which have been identified namely BPV-1 to BPV-6, then classified into two subgroup, A and B. Subgroup A consist of BPV1, BPV-2, BPV-5 form fibropapilloma which consist of dermal fibroblast and keratinocyte, subgroup B comprise of BPV-3 and BPV- 6 which caused epithelial papilloma with keratinocyte, while BPV-4 infects epithelial mucosa of upper part of gastrointestinal tract [7].

Hamad et al [8] added that six types of BPV have been describe, and recently four other types reported. BPV-1 causes teat and penile fibropapillomas, BPV-2 was associated with cutaneous warts, alimentary fibropapillomas and urinary bladder tumors; BPV-3 causes cutaneous papillomas. BPV-4 is associated with pure epithelial papillomas of the upper gastrointestinal tract; BPV-5 induces fibropapillomas of the udder; BPV6 causes papillomas of the teats; BPV-7/8 causes cutaneous papillomas; BPV-9/10 are associated with epithelial squamous papillomas of the udder.

Papillomaviruses are small about $55 \mathrm{~nm}$ in diameter, non-enveloped, icosahedral viruses, containing a double stranded, circular DNA genome about 8000 base pairs long. They found throughout higher vertebrates, mostly mammals and birds, causing cutaneous and mucosal tumours [9]. Pattanayak [10] added that bovine papilloma virus affecting cattle and horse and the same type of viruses have been isolated from papillomatus lesions of sheep, goat, swine, dog, cats, rabbit and human beings. Many studies of BPV infection reported in domestic animals such as cattle, birds and wild animal such as tapir, giraffe, antelope and zebras. It causes equine sarcoid in horses and donkeys as well [11].

In cattle such as horse, cows, sheep and goat, papillomatosis is observed in the area of neck and spread all over the skin surface. At first, papillomas grow around the ears, eyes, nose, neck or shoulders. In female cattle, papillomas often develop on the skin of the udders and nipples, back, chest and neck, legs, face and external genitalia. Initially the papilloma grows as big as the fingertip, and then enlarges like a grape [6].

Papillomatosis transmit to other animal through direct contact, food, repeated use of syringe, and contaminated pens equipment. Cattle with papillomatosis are clearly diagnosed by the occurrence of rough and not pain warts [5]. Papilloma is rarely noticed by breeders, thus it will spread to the entire body of the cow and infect other cows.

The predilection site of Bovine papilloma virus is mucosa and epithelial cells of the skin [12]. This virus cannot actively penetrate the skin of the host, therefore skin abrasions or open wounds are needed by the virus as a pathway for infection [13]. Skin lesions occur due to tattoos around the ears for ear tags, around the nose due to wounds on the nose strap and lesions due to exposure to barbed wire. The virus enters the epidermis and replicates in the basal epithelial cells. Viral replication causes proliferation of epithelial cells, which is characteristic of benign tumours such as papillomas [14]. Therefore, BPV infection due to viral exposure to one or more epithelial lesions causes infection, transformation and multiplication of basal cells and then develop into a benign tumour [15]. Recurrent papillomatosis can also occur due to several factors including genetic, hormonal disorders and suppression of the immune system [9].

Economic impact of the disease is clearly observed in loss of animal condition, which followed by secondary infection by bacterial, skin myasis, interfering lactation process, reduce animal price and sometimes hinders the sale. Furthermore, another disadvantage caused by papillomatosis is an economic loss, namely the performance of cattle looks poor because of the growth of papillomas that spreads over the body surface. This has an effect on the decline in the selling value of the cattle. The selling value of young cattle should be the same as the value of feeder cattle, but due to the widespread growth of papillomas, the cattle are only valued at the price of beef per kilo $[5,6]$.

The prevalence of bovine papillomatosis in northern oases recorded as $4.86 \%$. The prevalence was higher in females $(2.99 \%)$ than males $(1.87 \%)$. The prevalence was the highest in cattle less than one-year-old $(2.99 \%)$ [5]. Based on the results of interviews with local residents and livestock officers in the Lhoknga area, the estimated prevalence of papillomatosis was $10 \%$. Therefore, precise diagnosis of papillomatosis was need to overcome the disease.

\section{MATERIALS AND METHODS}

This case study was conducted in the Lhoknga area, Aceh Besar. Bovine Papiloma Virus (BPV) occur in 2 years old cow, which are Aceh cattle breed and are female. The method of examination includes clinical examination, hematology examination, and histopathological examination.

Clinical examination begins with a signalement and anamnesis with the livestock owner. The signalement data includes the name of the animal, sex, type of animal, race, age and body weight. Anamnesis data consists of information related to animal health conditions and disease history. The physical examination of the animals was carried out by observing the body surface and followed by palpation of the skin surface. Measurement of the animal's body temperature using a thermometer was done through rectal. The examination of the ears, eyes, nose, outer and inner mouth and observing the mucous membranes of the patient's eyes and anus were also conducted thoroughly.

The histopathological procedure was carried out ollowing the method of Kiernan et al [16]. Selected skin 
nodules from affected animals were surgically removed after local anesthesia then fixed in $10 \%$ buffered neutral formalin solution, dehydrated in gradual ethanol (70$100 \%$ ), cleared in xylene, and embedded in paraffin. Five micron thickness paraffin section were prepared and then routinely stained with hematoxylin and eosin dyes. The slide was also stained with Masson's trichrome staining following the modification of adaptation Goldner's Masson trichrome staining method. The sections were mounted with Canada balsam and covered with the cover slide to be ready for histopathological examination.

\section{RESULTS AND DISCUSSION}

\subsection{Clinical Examination}

The results of physical examination demonstrate that there were lumps of various sizes on facial area $(1-2 \mathrm{~cm})$, on orbital area (approximately $3 \mathrm{~cm}$ ), and on the area behind the ear which is the largest nodule with the size about $5 \mathrm{~cm}$. The lumps performanceS are cauliflower like, black to greyish in colour, and keratinized. An open wound or ulcer on the surface of the lumps was also observed (Figure 1).
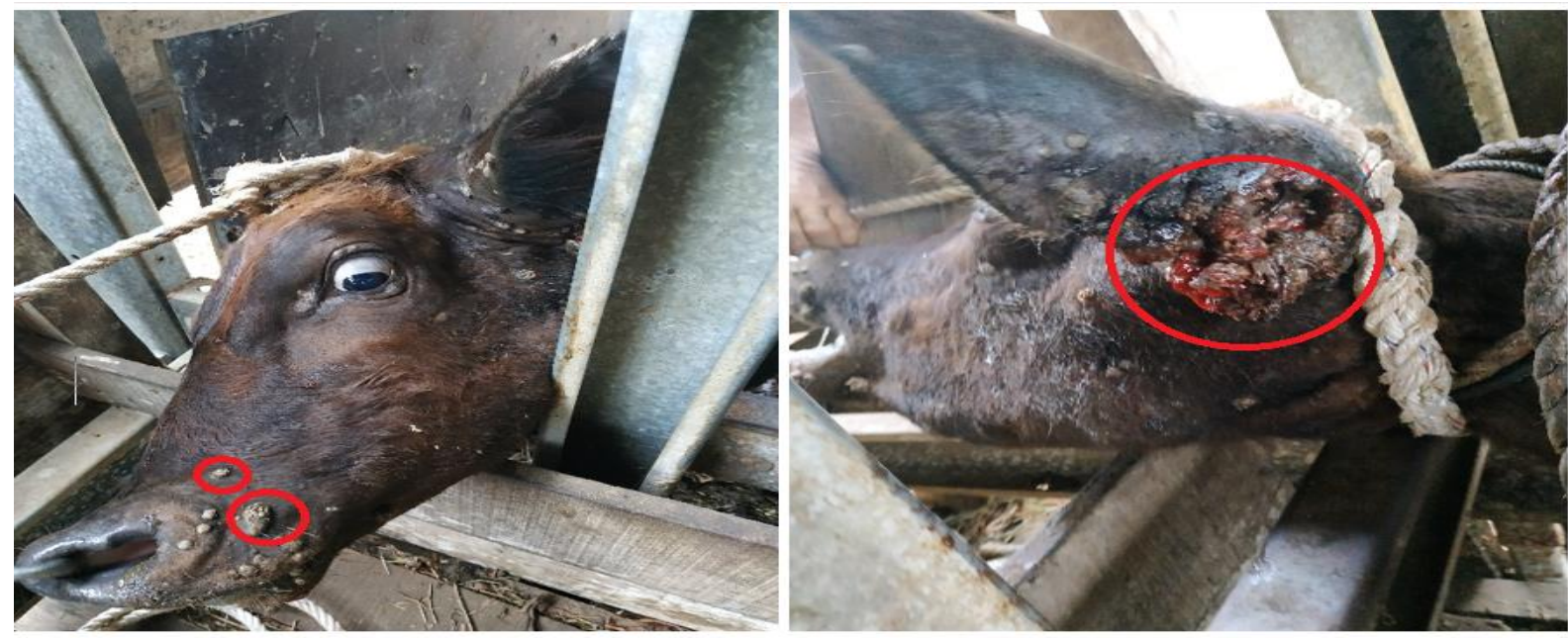

Figure 1 Lumps of papillomatosis on the head area (red circle) of Aceh cattle in Lhoknga.

Archana et al [17] reported that cows with papillomatosis showed various sizes of lumps on the neck, mouth, thighs, scrotum, vagina, and nipples. In addition, Nenad et al [18] reported that the most commonly seen area of this papilloma are on the nose, chin, lips, neck, shoulder and brisket region of the body. The warts are characterized by solid outgrowth of the epidermis with cauliflower like appearance.

These benign lesions generally regress naturally, but in very rare cases the papilloma becomes harder and become malignant neoplasia, especially in cases of carcinogenic cofactors such as consumption of ferns for a long period of time $[19,20]$. There are four main types of papillomatosis namely squat, pedunculated, flat, and tag. Although warts are less dangerous and disappear spontaneously over a long time period, however this case is reversible when the hygiene and cattle and pen management are not appropriate [21].

\subsection{Hematology Examination}

The results of blood tests showed an increase in the number of white blood cell (WBC), mean corpuscular haemoglobin concentration (MCHC), platelet (PLT), lymphocyte and monocyte, and a decrease in the number of haematocrit (HCT). The results of blood tests can be seen in Table 1 .

An increase in blood cells or immune cells such as thrombocytosis, leucocytosis, monocytosis, basophilia, eosinophilia, neutrophilia, or a decrease such as thrombocytopenia, leukopenia, monocytopenia, helps confirm the diagnosis. Likewise, the number of red blood cells and haemoglobin. Infiltration of inflammatory cells in tissues, changes in electrolytes, changes in enzymes, which can help diagnose any tissue or organ damage $[21,22]$. 
Table 1. Hematology Examination of papillomatosis Aceh cattle in Lhoknga.

\begin{tabular}{|c|c|c|c|c|}
\hline Examination & Result & Normal range (Jain, 1986) & Unit & Interpretation \\
\hline WBC & 14.24 & $4.0-12.0$ & $10^{3} / \mu \mathrm{L}$ & Increase \\
\hline RBC & 4.67 & $5.0-10.0$ & $10^{6} / \mu \mathrm{L}$ & Normal \\
\hline HGB & 6.7 & $8.0-15.0$ & $\mathrm{~g} / \mathrm{dL}$ & Normal \\
\hline HCT & 17.0 & $24.0-64.0$ & $\%$ & Decrease \\
\hline MCV & 36.4 & $40.0-60.0$ & $\mathrm{fL}$ & Normal \\
\hline MCH & 14.3 & $11.0-17.0$ & $\mathrm{Pg}$ & Normal \\
\hline MCHC & 39.4 & $30.0-36.0$ & $\mathrm{~g} / \mathrm{dL}$ & Increase \\
\hline PLT & 6.6 & $0.8-1.1$ & $\mathrm{X} 10^{3} / \mu \mathrm{L}$ & Increase \\
\hline Neutrophil & 1.92 & $0.6-4.0$ & $\mathrm{X} 10^{3} / \mu \mathrm{L}$ & Normal \\
\hline Lymphocyte & 9.53 & $2.5-7.5$ & $\mathrm{X} 10^{3} / \mu \mathrm{L}$ & Increase \\
\hline
\end{tabular}

Platelet abnormalities include thrombocytopenia and thrombocytosis caused by many factors. Apart from platelet abnormalities in terms of quantity or number of platelets, platelet abnormalities from the aspect of quality can also occur, causing impaired platelet function. Platelets play an important role in the blood clotting process, so that platelet abnormalities can manifest in bleeding [23]. The increase in WBC/leukocytes is influenced by the increase in the number of lymphocytes and monocytes. Lymphocytosis is a condition in which lymphocyte levels are increased, this condition is caused by several factors, including malignant lymphoma, viral/bacterial infections, stress, and trauma [22, 24]. Mean corpuscular haemoglobin $(\mathrm{MCH})$ is the concentration calculated from the haemoglobin per red blood cell regardless of the size of the red blood cells. The MCHC value was used to determine the anaemia condition of cattle based on the haemoglobin concentration. MCHC can decrease due to heat stress which causes the blood's ability to bind oxygen to slightly lower [22]. MCHC is usually increased in cases of spherocytosis, not pernicious anaemia [23].

The condition in which the decrease in erythrocyte count, haemoglobin and haematocrit values from their normal values is called anaemia [22]. Increased haematocrit value can also occur due to decreased blood plasma volume such as dehydration. Dehydration can also be caused by insufficient nutrition and inadequate environment [24].
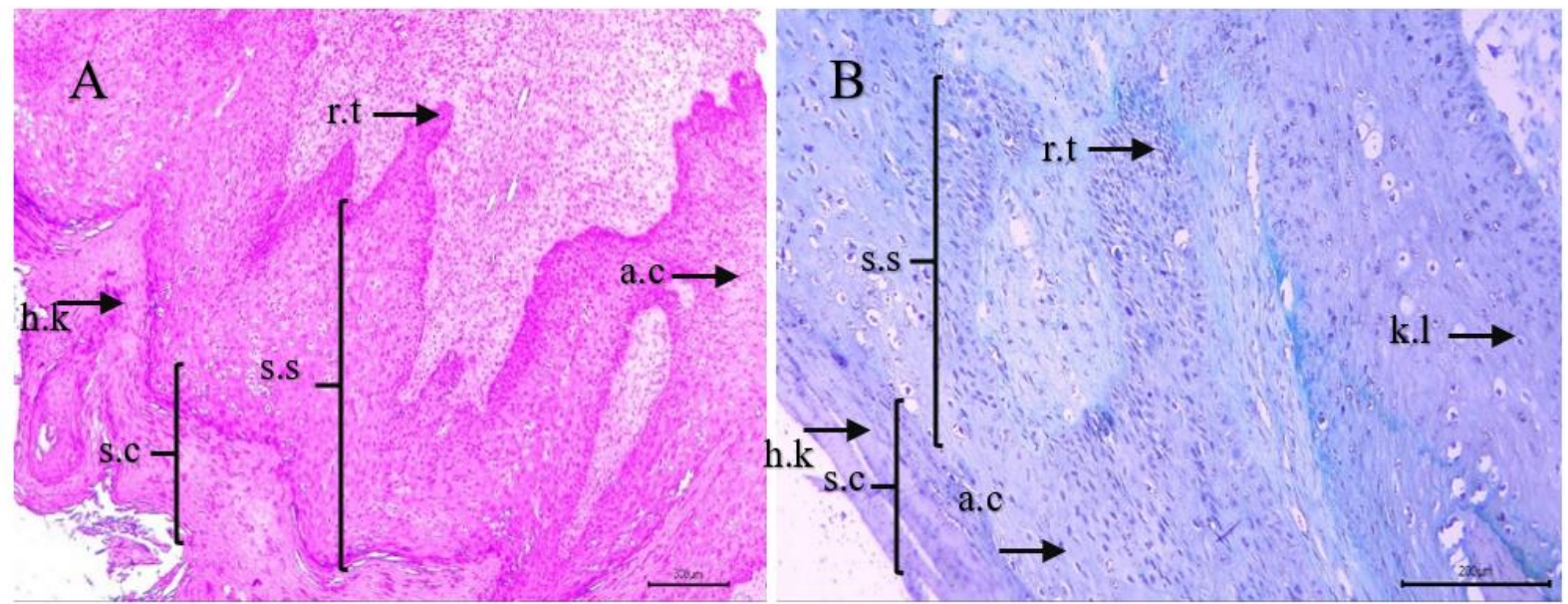

Figure 2 Histopathological feature of papillomatosis in Aceh cattle in Lhoknga using hematoxylin eosin (A) and Masson's trichrome (B) staining (4x and 10x). Stratum corneum (s.c), stratum spinosum (s.s), hyperkeratosis (h.k) in the stratum corneum layer, acanthosis (a.c), rete ridge (r.t) and coilocyte cells (k.l). 

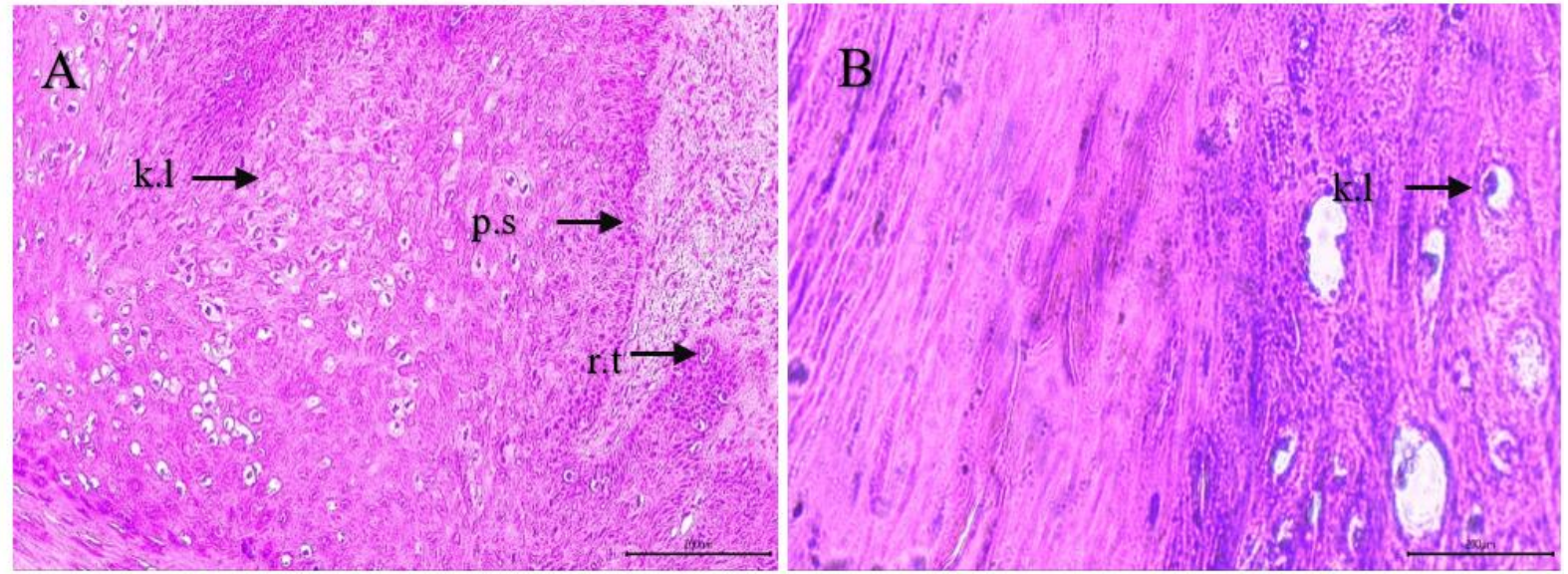

Figure 3 Histopathological findings of papillomatosis in Aceh cattle in Lhoknga (H\&E) 10x (A) and 40x (B). Rete ridge (r.t), coilocyte cells (k.l), proliferation of epithelial cells to form papillae (p.s)

\subsection{Histopathological Examination}

Observation on histopathological slide found protruding epithelium (Rete Ridge) of the stratum spinosum due to cell hyperplasia. In addition, acanthosis was also observed in the stratum spinosum and hyperkeratosis of the stratum corneum, coilocyte cells and proliferation of connective tissue (Figures 2 and 3).

This results in line with Zwandor et al. [25], that reported the histopathology of the zebu with papillomatosis found ortokeratotic hyperkeratosis with increased granular cell and kertohyaline granules, hyperplastic non-cornified epidermis with formation of rete ridges and downward pegs projecting into the dermis. Furthermore, acanthotic spinous cells, fibrosis and mononuclear cellular infiltration (fibropapilloma) have observed. In addition, there were lesions caused by BPV infection, such as hyperkeratotic and colloidal cells, as well as lymphocyte and monocyte infiltration. Papillomatosis appears histologically as a focal lesion of thickened epithelial folds with enlarged keratinocytes containing a dark, shrunken nucleus surrounded by the coilocytes. The underlying tissue contain a small number of inflammatory cells often considered histologically normal [26].

Papilloma infection lead to the damage of the cattle skin almost on the entire surface of the skin. To date, there is no specific drug for the treatment of papilloma. Usually the treatment of papillomas in the field carried out by surgical techniques. The success of the surgical method with incisions depends on the surface area of the body infected with papillomas [27].

Treatment of bovine papillomatosis with autogenous vaccine produced by grinding and suspending wart indicate variable results. It proven that autogenous vaccines prepared from sterile homogenized warts, administered twice-prevented new cases, and treated sick animals [28].

\section{CONCLUSION}

Bovine Papillomavirus can be diagnose from clinical examination with the occurrence of various sizes of warts on the skin surface characterized by cauliflower like, black to greyish in colour, and keratinized. Histopathologically, there are hyperkeratocytes, acanthosis, and proliferation of epithelial cells to form papilla and coilocyte cells.

\section{AUTHORS' CONTRIBUTIONS}

BP, S, R, MH, HA, DA, HF, and RA have contributed equally to the work.

\section{REFERENCES}

[1] C.N. Thasmi, T.N. Siregar, S. Wahyuni, D. Aliza, H. Hamdan, B. Panjaitan, N. Asmilia, H. Husnurrijal. Estrus performance and steroid llevel of repeat breeding aceh cattle synchronized with PGF2 $\alpha$, Veterinaria 66(1) (2017) 36-41.

[2] M.A.N. Abdullah. Genetic characteristic of Aceh cattle using phenotypic diversity analysis, mitochondria DNA and microsatellite DNA DLoop area. Dissertation. Postgraduate Program. IPB University, Bogor, 2008.

[3] J. Jamaliah. Conservation of Aceh cattle. Balai Pembibitan Ternak Unggul (BPTU), Indrapuri, Aceh, 2010

[4] A. Rasyid, Y. Adinata, Y. Yunizar, L. Affandhy. Fenotypic Characteristic and Development of 
Aceh Cattle in Aceh Province. Maduranch Animal Husbandry Journal, 2(1) (2017) 1-12

[5] F.A. Salib, H.A. Farghali. Clinical, epidemiological and therapeutic studies on bovine papillomatosis in Northern Oases, Egypt in 2008. Vet. World 4(2) (2011) 53-59.

[6] I.C.I. Ugochukwu, S.I. Aneke, I.S. Idoko, N.A. Sani, A.J. Amoche, W.Ph. Mshiela, R. E. Ede, N.D.G. Ibrahim, C.I.O. Njoku, A.K.B. Sackey. Bovine Papilloma: Aetiology, pathology, immunology, disease status, diagnosis, control, prevention and treatment: A review. Comp. Clin. Pathol. 28 (2018) 737-745. DOI: https://doi.org/10.1007/s00580-018-2785-3.

[7] A.N.F. Neamat-Allah. Immunological, haematological, biochemical, and histopathological studies on cows naturally infected with lumpy skin disease. Vet. World $8(9) \quad$ (2015) 1131-1136. DOI: 10.14202/vetworld.2015.1131-1136.

[8] M.A. Hamad, A.S. Al-Banna, N.Y. Yaseen. Treatment of bovine papilloma. Proceeding of the Eleventh Veterinary Scientific Conference, 2012 pp. 25-32.

[9] M.S. Campo, W.F.H. Jarret, W. O'neil, R.J. Barron. Latent papilloma virus infection in cattle. Res. Vet. Sci. 56 (1994) 151-157

[10] S. Pattanayak. Autohaemotherapy in bovine papillomatosis. INTAS POLIVET 5(1) (2004) 16-17.

[11] H. Trewby, G. Ayele, G. Borzacchiello, S. Brandt, M.S. Campo, C. Del Fava, J. Marais, L. Leonardi, B. Vanselow, R. Biek, L. Nasir. Analysis of the long control region of bovine papillomavirus type 1 associated with sarcoids in equine hosts indicates multiple cross-species transmission events and phylogeographical structure. J. Gen. Virol. 95(12) (2014) 27482756.

[12] L.T. Chow, T.R. Broker. Mechanisms and regulation of papillomavirus DNA replication. In: Campo MS (Ed) Papillomavirus research: from natural history to vaccines and beyond. Caister Academic Press, Norfolk, 2006 pp 53-71.

[13] L. Nasir, S. Brandt. Papillomavirus associated diseases of the horse. Vet. Microbiol. 167 (2013) $159-167$

[14] W.A. Hagan, D.W. Bruner, J.H. Gillespie, J.F. Timoney, F.W. Scott, J.E. Barlough.. Microbiology and infectious diseases of domestic animal, Eight Ed, Cornell University Press, United States of America, 1988.

[15] K.V. Shah, P.M. Howley. Papillomaviruses. In: Fields virology, $3^{\text {rd }}$ Ed, Lippincott - Raven Publishers, Philadelphia, 1996 pp. 2077-2101.

[16] J.A. Kiernan. Histological and histochemical method: Theory and pratice. $2^{\text {nd }}$ ed. Pergamon Press, New York, 1990.

[17] S.N. Archana, A. Prasad, J. Davis, T.X. Seena. Bovine Papillomatosis and its treatment under farm condition. Int. J. Curr. Microbiol. App. Sci. 8(4) (2019) 2880-2884. DOI: https://doi.org/10.20546/ijcmas.2019.804.336.

[18] T. Nenad, Z. Zeljko, S. Vilim, K. Snjezana, B. Tomislav, K. Mario, C. Stipica, B. Ljubo, M Zoran. Cattle papillomatosis. Veterinarski Arhiv 75 (2005) 391-397

[19] G. Borzacchiello, F. Roperto. Bovine papillomaviruses, papillomas and cancer in cattle. Vet. Res. 39 (2008) 1-10.

[20] D.J. Meuten, Tumor in domestic animals. $4^{\text {th }} \mathrm{Ed}$, A Blackwell Publishing Commpany, Iowa State Press, Iowa, 2002.

[21] S. Sharma, K.B. Singh, B.K. Bansal, D.K. Sharma. Clinical symptomatology and epidemiological observations on teat skin lesions in buffaloes. Buffalo Bulletin 24 (2005) 12-16.

[22] O.M.M Borges, C.L.M. Araujo, G.C. Ramalho, R.M.N. da Silva, A. Tanikawa, A.P. de Souza, Effects of autohemotherapy on hematologic parameters and morphology of canine oral papillomatosis. Acta Sci. Vet. 45(suppl1) (2017) 211.

[23] A. Shefaa M. El-Mandrawy, R.T.M. Alam, Haematological, biochemical and oxidative stress studies of lumpy skin disease virus infection in cattle. J. Appl. Anim. Res. 46(1) (2018) 1073-1077. DOI: https//doi.org/10.1080/09712119.2018.1461629.

[24] L. Roland, M. Drillich, M. Iwersen, Hematology as a diagnostic tool in bovine medicine. J. Vet. Diagnost. Investig. 26(5) (2014) 592-598. DOI: $10.1177 / 1040638714546490$.

[25] N.J. Zwandor, Y. Akalusi, S.S. Ngulukun, C.A. Meseko, B.O. Akanbi, J.A. Adedeji, I.O. Fagbamila, Severe cutaneous bovine papillomatosis in a cattle herd. Vom. J. Vet. Sci. 5(1) (2008) 67-72. 
[26] J.S. Munday. Bovine and human papillomaviruses: A comparative review. Vet. Pathol., 51(6) (2014) 1063-1075

[27] M. Sreeparvathy, C. Harish, K.S. Anuraj. Autogenous vaccination as treatment method for bovine papillomatosis. Ind. J. Livestock Sci. 2 (2011) 38-40.

[28] P.A. Nehru, S. Sunandhadevi, T. Rama, N. Muniyappan. Eficacy of auto-hemotherapy in bovine teat papillomatosis: A case report. Adv. Anim. Vet. Sci. 5(8) (2017) 350-351. Doi: http://dx.doi.org/10.17582/journal.aavs/2017/5.8 .350.351. 